\title{
Description of Soft Sediment Deformational Structure of the Campano-Maastrichtian Gombe Formation of the Northern Benue Trough, N.E. Nigeria
}

\author{
B. Shettima ${ }^{1}$, A. Suleiman ${ }^{2}$, A. H. Abdulkarim ${ }^{3}$ \\ 1- Department of Geology, University of Maiduguri, Borno State, Nigeria. \\ 2- Department of Geology, Gombe State University, Gombe State, Nigeria. \\ 3- National Centre for Petroleum Research and Development, A.T.B.U. Bauchi State, Nigeria.
}

\begin{abstract}
Several soft sediment deformational structures were identified during fieldwork survey carried out on exposures of Gombe Formation in the Gongola sub-basin of the Northern Benue Trough at Gombe and environs. These soft sediment deformational structures includes: simple internal cusps, which occur wide spread across a single bed or intermittently across several beds, and slump structures that are represented by complex recumbent folds and concave upwards structures. These structures are proxy to syn-depositional energy operating within the depositional environment and this current research aims to evaluate their trigger mechanism. These deformational structures are commonly hosted in the mouth-bar deltaic sequences of the Gombe Formation. The deltaic setting is usually a locus for high sediment influx and accumulation. This may have generated high quantum of depositional energy which was probably responsible for the development of the syn-depositional soft sediment depositional structures in the Gombe Formation during Campano-Maastrichtian times.
\end{abstract}

KEYWORDS: Gombe, Sandstone, Gongola Basin, soft sediment Benue trough.

[Received May 23 2017; Revised September 11 2017; Accepted October 27 2017]

\section{INTRODUCTION}

The Campano-Maastrichtian Gombe Formation is located in the Gongola Sub-basin of Northern Benue Trough and it forms a north-south outcrop in western margin of the basin with a width of about $15 \mathrm{~km}$ (Figure 1) (Dike and Onumara, 1999).

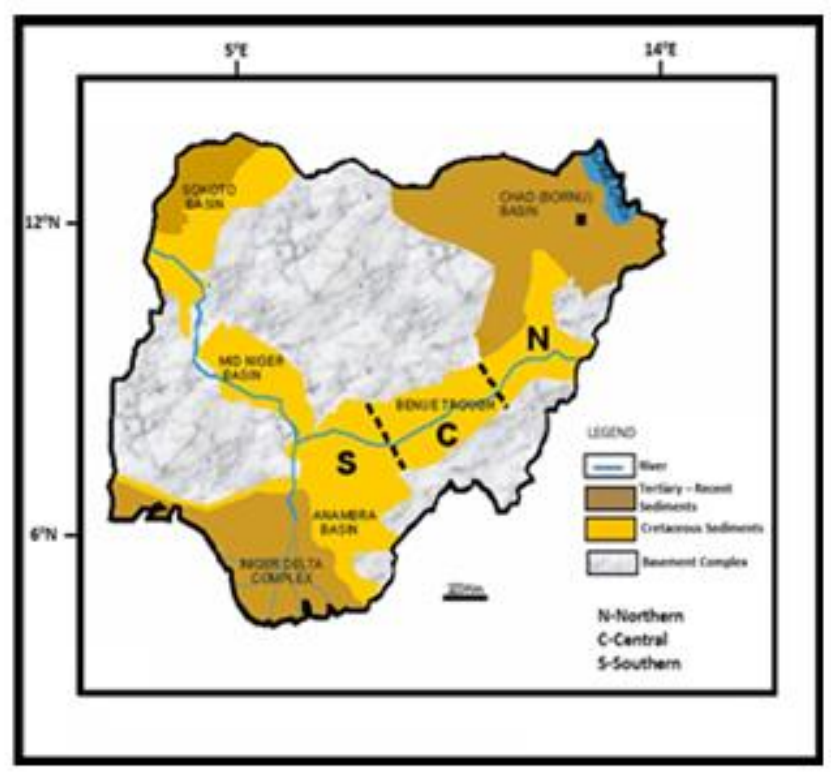

Figure 1: Geological Map of Nigeria showing the Benue Trough (modified from Abubakar et al., 2008).

The area of study lies between latitude $10^{\circ} 10^{\prime} \mathrm{N}$ and $10^{\circ} 25^{\prime} \mathrm{N}$ and latitude $10^{\circ} 05^{\prime} \mathrm{E}$ and $10^{\circ} 20^{\prime} \mathrm{E}$. The Gombe *Corresponding author's e-mail address: drsab2010@yahoo.com
Formation represents the youngest Cretaceous unit in the Gongola Sub-basin and has attained a maximum thickness of about $320 \mathrm{~m}$ (Dessauvagie, 1975). Lithologically, it comprises of fine to very fine grained sandstone, siltstones, mudstones and shales which are locally associated with thin low grade coal interbeds (Dike, 1993). Layers with soft sediment deformational structures are abundant in its upper arenaceous part.

Soft sediment deformational structures form due to disturbances of sediment during or after deposition, consolidation or burial (Boggs, 1987; Owen, 1996). They are common in sands and sandstones that are loosely packed and rapidly deposited (Lowe, 1975; Maltman, 1994) and are generated through the process of Liquefaction, fluidization or a combination of these processes (Lowe, 1975; Owen, 1987). These structures display wide variety of shapes and forms, and occur in between units that are undeformed, and lithologically, there are no variations between them. Deformations can be induced into sediment either by tectonic or non-tectonic processes and their imprints can be left behind in the sediments affected.

Deformation can occur during depositional process (syndepositional), after deposition but before the sediment are covered by younger layers (meta-depositional) and after beds has been covered by younger layers (post-depositional). Earlier occurrences of these structures from the Gongola Sub - basin has been reported by Samaila et al. (2006) in the Bima Formation, Shettima et al. (2006) in the Yolde Formation and the currently studied herein are presented in literature for the very first time.

doi: http://dx.doi.org/10.4314/njtd.v14i2.2 
This paper is aimed at evaluating the origin of the soft sediment deformational structures of the Gombe Sandstone by applying the methods of Owen (1987) and in association with the works of Anand and Jain (1987); Obermier (1996); Rossetti (1999); Jones and Omote (2000) on diagnosis of earthquake origin of soft sediment.

\section{TECTONO - SEDIMENTARY SETTING}

The Benue Trough is a major NE - SW trending rift basin of $50-150 \mathrm{~km}$ width. It extends for over $1000 \mathrm{~km}$ starting from the northern margin of the Niger Delta in the south to southern margin of the Chad Basin in the north (Figure 1). The trough contains over $6000 \mathrm{~m}$ of Cretaceous Tertiary sediments associated with volcanics of which those pre-dating the mid-Santonian have been compressionally deformed, faulted and uplifted in several places. It is geographically subdivided into lower, middle and upper portions (Figure 1). The Northern Benue Trough is $\mathrm{Y}$ shaped, made up of three arms namely: the $\mathrm{E}-\mathrm{W}$ trending Yola Arm, N-S trending Gongola Arm and the NE-SW trend main arm (Muri-Lau Arm) as shown in Figure 2.

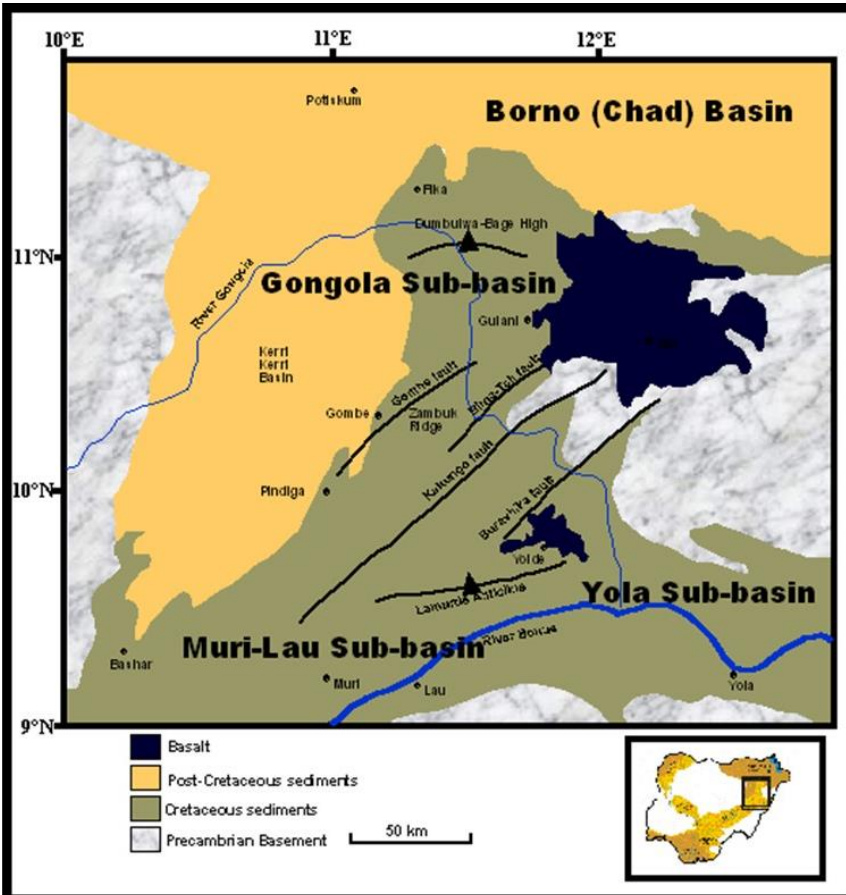

Figure 2: Geological map of the Northern Benue Trough (modified from Zaborski et al. 1997).

The Northern Benue Trough is believed to have formed from extensional processes during the Late Jurassic - Early Cretaceous separation of the continents of Africa and South America through the process of rifting (Grant, 1971; Olade, 1975). However, Benkhelil (1989) is opposed to this rift model, suggesting that the reactivation of the Late Pan African transform fault in the South Atlantic during the Cretaceous developed sets of sinistral strike - slip faults are responsible for the development of the sub - basins in the Northern Benue Trough.

The sedimentary sequence infilling of the Northern Benue Trough is made up of continental, transitional and marine deposits and they range from Aptian to Paleocene (Rabelle, 1990; Zaborski et al., 1997 and Dike, 2002).

The Bima Formation, a continental formation, represents the basal part of the sedimentary succession in all the three arms of the Northern Benue Trough shown in Figure 3.

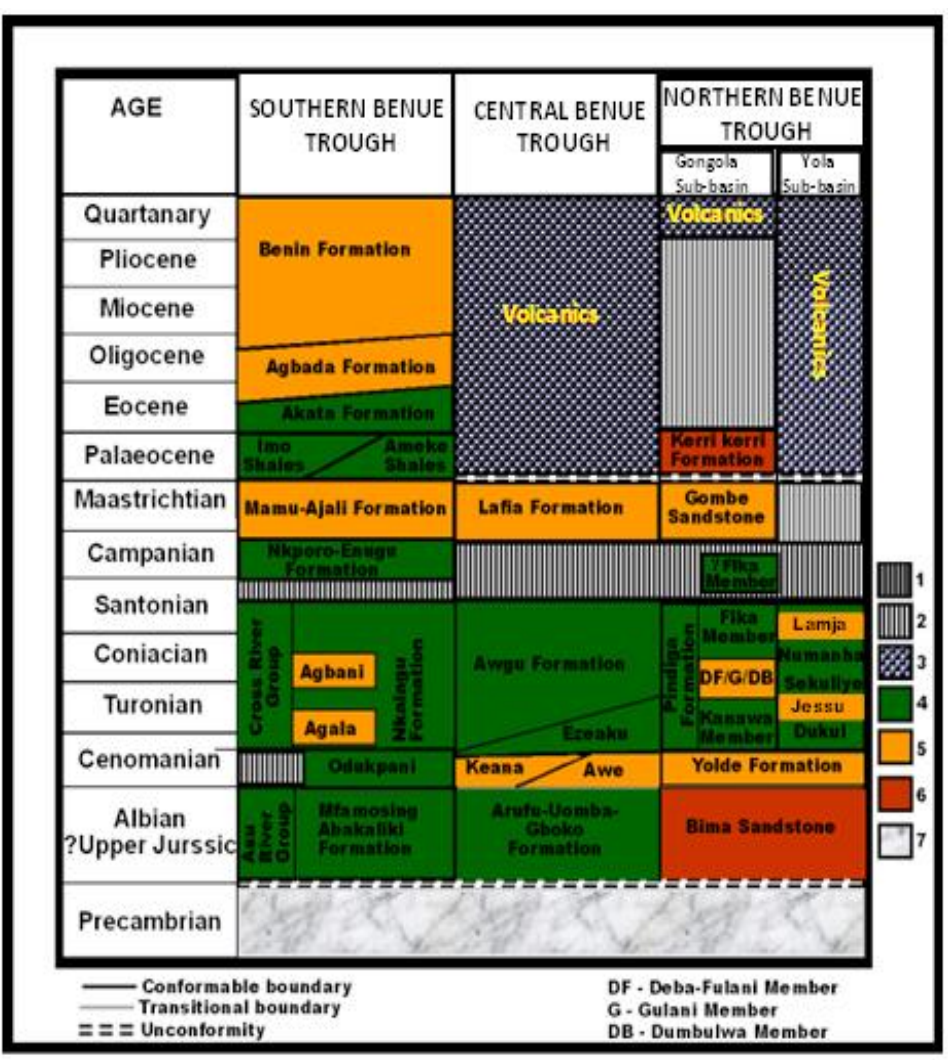

Figure 3: The stratigraphy of the Benue Trough (modified from Obaie et al.. 1999).

1-Hiatus, 2-Santonian and Cenomanian tectonism, 3-Basalt, 4-Marine sediments, 5-Transitional-marine sediments, 6-Continental sediments, 7-Basement complex

It unconformably overlies the Precambrian basement complex and consists of three siliciclastic members: the Lower Bima (B1), the Middle Bima (B2) and the Upper Bima (B3). Its lithology and depositional environments have been discussed by several authors (Carter et al., 1963; Allix, 1983; Guiraud, 1990). The Yolde Formation lies conformably on the Bima Formation in the whole of the Northern Benue Trough. This formation of Cenomanian age (Lawal and Maullade, 1986) represents the beginning of marine incursion into this part of the Benue Trough. The Yolde Formation was deposited in a barrier island/deltaic setting (Abubakar, et al., 2006; Shettima, 2007).

In the Gongola Sub - basin (Arm), the Yolde Formation is conformably overlain by the Pindiga Formation which is lateral equivalent to Gongila Formation and Fika Shale (Popoff et al., 1986), and they all represent a full marine incursion into the Gongola Arm (Figure 3). The estuarine/deltaic Gombe Formation of Maastrichtian age overlies the Pindiga Formation and it represents the youngest Cretaceous sediments in the Gongola Basin.

The Paleocene Kerri-Kerri Formation unconformably overlies the Gombe Sandstone and represents the only record 
of Tertiary sedimentation in the Gongola Basin (Adegoke et al., 1978 and Dike, 1993).

In the Yola Sub - basin (Arm), the Dukul, the Jessu, the Sekuliye, the Numanha Shales and the Lamja Sandstones are the Upper Cenomanan-Santonian equivalents of the Gongila and Pindiga Formations of the Gongola Basin. The TuronianSantonian deposit in the Yola Basin are lithologically and paleoenvironmentally similar to those in the Gongola Basin, except the Lamja Sandstone which is dominated by marine sandstone (Carter et al., 1963).

\section{METHODOLOGY AND DATASET}

Topographic, structural and geological maps of Gombe town and environs were employed in the fieldwork of this research to identify potential areas where the CampanoMaastrichtian Gombe Formation is well exposed. Along these well exposed outcrops, identified soft sediment deformational structures are carefully studied taking into account and records of their types, lithology, thicknesses and the nature of the deformed sedimentary structure within which they are embedded. Temporal and spatial distribution of these structures will also be measured and evaluated to determine the extent of their regional distribution.

The Gombe Sandstone host different types of soft sediment deformational structures and these includes: cusps, slumps, recumbent folds and chaotic assemblages. They are generally composed of fine - very fine grained sandstone and are generally sandwiched between undeformed units that have the same textural characteristics.

Cusps commonly occur at several levels with distinctive dish and pillar structure. This is a localized water escape structure that is syn-depositionally formed (Lowe, 1975) and they arise due to vertical displacement during fluidization (Owen,1995). In the Gombe Sandstone only internal cusps were identified and they tend to occur in layers, probably originating from the deformation of parallel laminated beds (Figure 4, 5, 6 and 7). This may indicate that liquefaction and fluidization were short-lived and the structure probably developed at the top of liquefied bed (Owen, 1987).

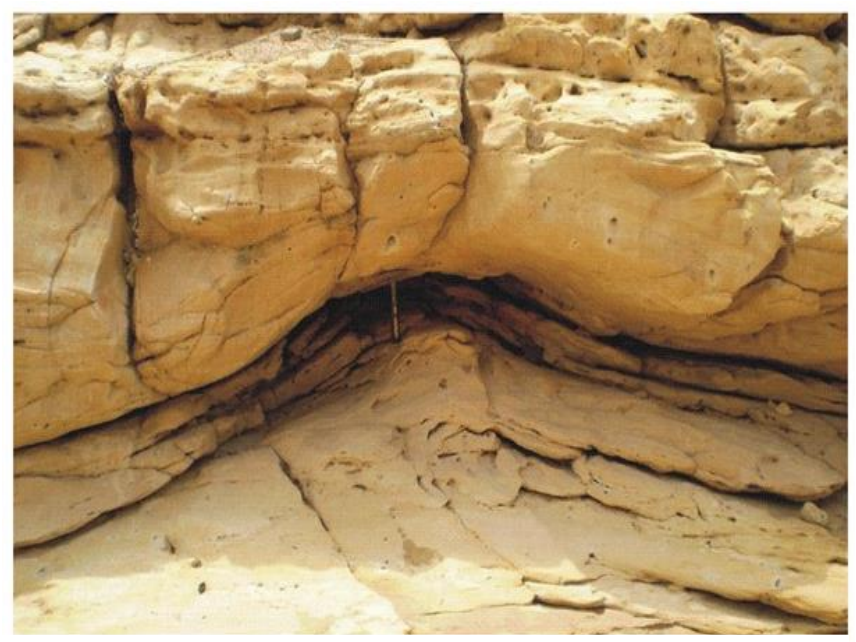

Figure 4: An outcrop of Gombe Formation showing internal cusps at F.C. E. Gombe University stream (N10'15.837', E11'10.041').

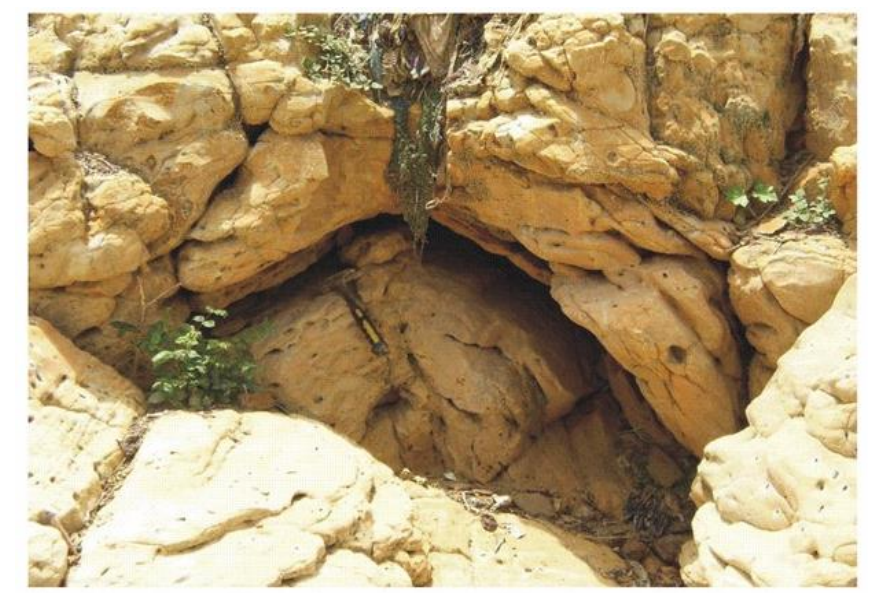

Figure 5: An outcrop of Gombe Formation showing internal cusps at London Dorawa stream (N10'14.923', E11'10.271').

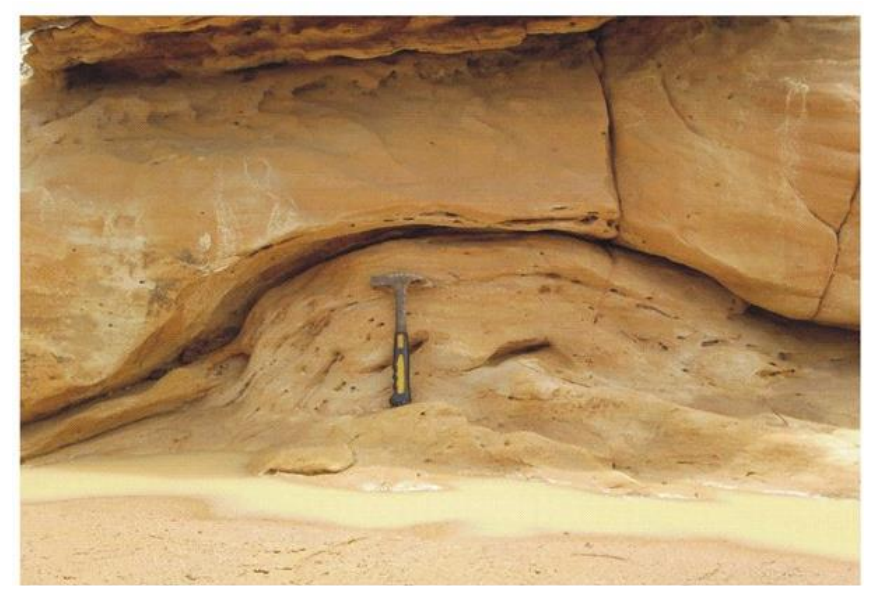

Figure 6: An outcrop of Gombe Formation showing internal cusps at F.C.E. Gombe stream (N10'15.631', E11'10.528').

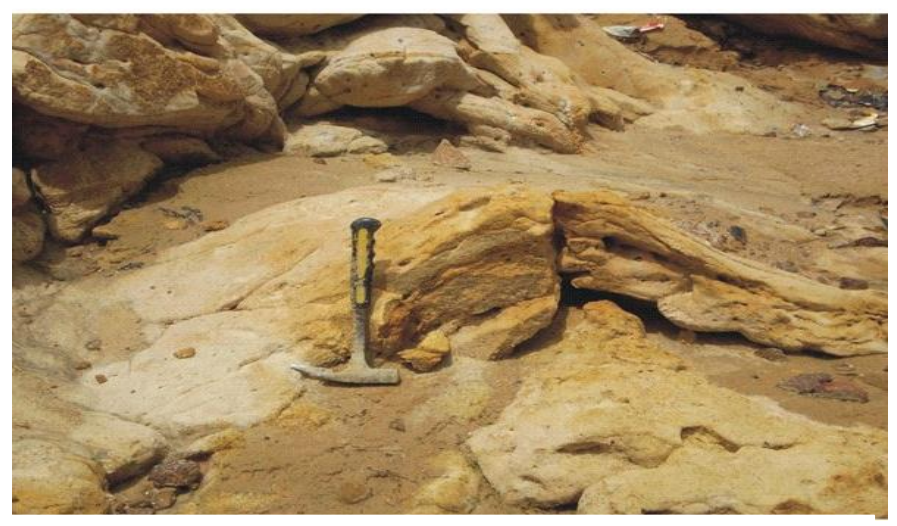

Figure 7: An outcrop of Gombe Formation showing internal cusps at F.C.E. Gombe stream (N10'15.421', E11'10.187').

Chaotic assemblages are meta-depositional and laterally extensive units of pervasive deformation consisting of disorganized assemblage of structures (Owen, 1987). These structures in the Gombe Sandstone shows intricate crumpling of the primary sedimentary structure which may have developed through high degree of fluidization considering the complete distortion of the initial structure (Figure 8). These structures generally form through vertical driving forces that are being generated by seismic shock (Owen, 1987). 


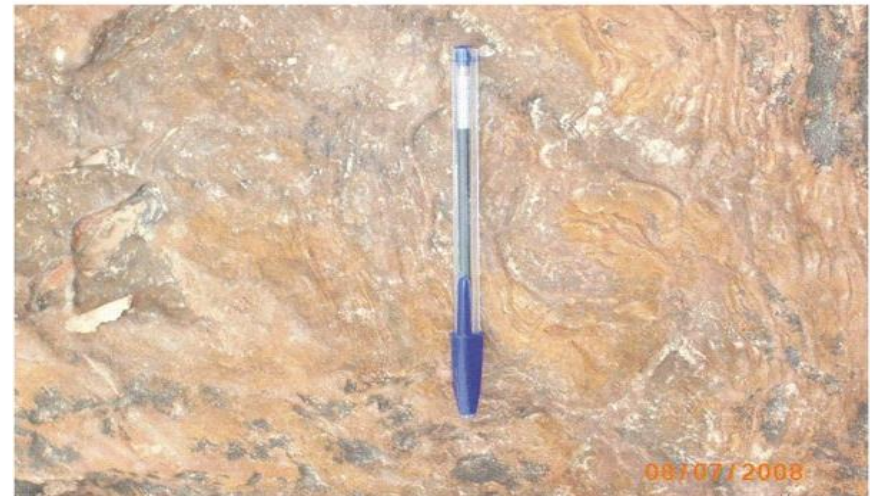

Figure 8: An outcrop of Gombe Formation showing Chaotic units at F.C.E. Gombe stream (N10'15.057', E11'10.644').

Syn-depositional slump with varying morphology are very common soft sediment features in the Gombe Sandstone and they occur in the form of simple and complex fold type. The large complex type soft sediment deformational structure are observed to occur in the thick fine grained facies and they are represented by inverse or recumbent folds having relatively irregular shape (Figure 9). The overturned flank lies horizontally and merges on to the overlying horizontal layer and its complexity increases towards the base, with more complicated structures appearing.

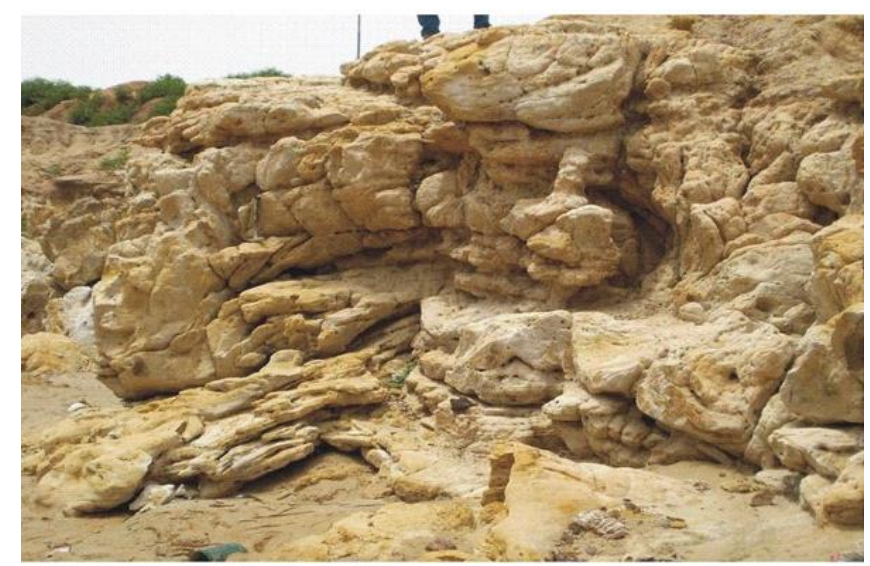

Figure 9: An outcrop of Gombe Formation showing recumbent fold at A.T.C. Gombe stream (N10'14.520', E11'10.117').

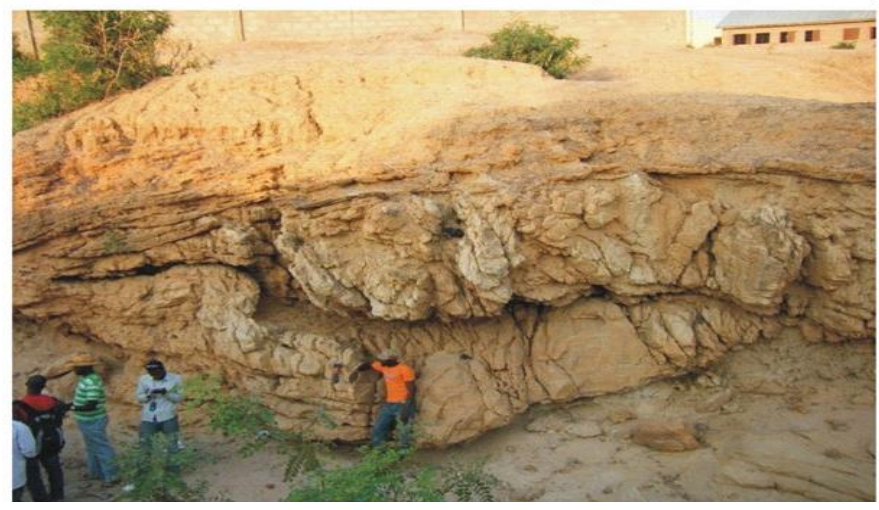

Figure 10: An outcrop of Gombe Formation showing Slump structure Pantami stream (N10'16.034', E11'10.226).
The concave upward structure develops locally in the folded strata and it exhibits a broad concave layer (Figure 10). This structure is about $1.2 \mathrm{~m}$ thick and considering its relative position with respect to the underlying sediment, it may be suggested to have formed due to overloading of sandstone on clayey plastic sediment.

\section{DISCUSSION}

The Gombe Formation is composed of deltaic sequences defined by thick claystone facies of the pro-delta clays at base, passing upwards to interbedded sandstone and claystone facies of the delta slope and capped by thick sandstone facies of the delta front sands (Dike and Onumara, 1999). The delta front sands commonly host the soft sediment deformational structures, occurring mostly as cusps in the form of simple internal cusps. They appear to be laterally discontinuous zones of laminations trending at high angle to the bedding which are either widespread across the bed or across several beds and they range in size in the order of tens of centimeters.

The geometry of the cusps may suggest that they may have resulted from vertical displacement and it is only sand that is involved. Slump deformational structures were observed to occur in the form of complex recumbent fold and concave upwards structure and they are confined between undeformed beds at their upper and lower limits. From the concave upwards structure, it is apparent that the deformation event involved slumping and sliding and these slump folds are interpreted as a product of earthquake - related slope failure and slumping (Kleverlan, 1987; Guiraud and Plazait, 1993; Bose et al., 1997).

Considering the fact that there were no volcanics reported in the Campano-Maasstrichtian times and the presences of growth faults in the deltaic sequences of the Gombe Formation, it could be suggested that the trigger mechanism responsible for the deformation of the soft sediment structure of the Gombe Formation may have been stress regimes associated with depositional processes. Sediments commonly deform to accommodate stress acting within depositional environments, as a consequence of reduction of the shear strength of the deposits (Lowe, 1975; Allen, 1977 and Owen, 1987).

Deltaic environments are usually associated with rapid deposition of saturated sand materials resulting into overloading of sediments thereby developing stress, causing substrate instability and increasing susceptibility ramp failure and mass sediment transport ultimately leading to deformation. The deformation is seismically aided because the preferentially movement due to overloading as a consequence of the excessive and rapid sediment influx generates stress that usually translates to seismic energy.

The degree of influence of seismic shock on sediments deposited on a given slope depends largely on their textures and grain size (Seilacher, 1984), sands and silt are fluidized easily and can form soft sediment deformational structures, however, mud tend to behave differentially, because of their cohesiveness and plastic nature. This is the more reason why deformations have not been observed in claystone beneath the concave upwards structure. The intermittent occurrence of the deformational structures at several stratigraphic levels may 
account for periods of high sediment outburst and discharge in the deltaic system of the Gombe Formation.

\section{CONCLUSION}

In the Gombe Formation, the dominant soft sediment deformational structure are generally simple internal cusps and are typically confined to the thick sandstone facies that were formed in delta front sub-environment. The trigger mechanism for this deformation are induced by the energy associated with ramp failure as a consequence of sediment overloading due very high sediment influx at ramp margins. Stresses generated by this energy deformed the unconsolidated sediments of the Gombe Formation leading to the development of cusps and slump syn-sedimentary structures.

\section{REFERENCES}

Abubakar, M. B., E. F. C. Dike, S. Bukar and A. Tukur (2006). Lithostratigraphy and Paleoenvironments of deposition of the Yolde formation of the Gongola Basin, Upper Benue Trough, Nigeria. Nig. Min. Geosci. Soc. $42^{\text {nd }}$ Annual International Conference, Kaduna, Abstract vol., pp48.

Adegoke, O. S., R. E. Jan du Chew, A. E. Agumanu and P. O. Ajayi, (1978). Palynology and age of the KerriKerri Formation, Nigeria, Revista Espanola Micropalacotologia 10: 2-283.

Allix, P. (1983). Environments Mesozoiques de la parite nord-orientale du fosse de la Benue (Nigeria) stratigraphie seimentologic evolution geodynamic. Trarause Laboratorie Science terre St. Jerome Marselles (B)21: 1-200.

Anand, A. and Jain, A. K. (1987). Earthquakes magnitude-frequency, epicentral distances and soft sediment deformation in sedimentary basins. Sedimentary Geology, 46: 67-75.

Benkhelil, J. (1989). The origin and evolution of the Cretaceous Benue Trough (Nigeria). Journal of African Earth Sciences, 8: 251-282.

Boggs, S. (1987). Principles of Sedimentology and Stratigraphy. Maxwell Macmillan Intern. Publ. Co., New York.

Bose, P. K., S. Banerjee and S. Sakar, (1997). Slope controlled seismic deformation and tectonic framework of deposition: Koldaha Shales, India. Tectonophysics, 269: 151169.

Carter, J. D., Barbers, W., Tait, E.A. and Jones, G.P., 1963. The Geology of parts of Adamawa, Bauchi and Borno provinces in North Eastern Nigeria. Bulletin of Geological Survey of Nigeria, 30: 1-99.

Dessauvagie, T. F. J. (1975). Explanatory notes to the geology map of Nigeria. Journal of Mining and Geology, 9: 3-28.

Dike, E. F. C., (2002). Sedimentation and Tectonics Evolution of the Upper Benue Trough and Bornu Basin, North-Eastern Nigeria. Nig. Min. Geosci. Soc. 38 Annual International Conference Port Harcourt 2002 Abstract Vol.

Dike, E. F. C., (1993). The Statigraphy and structure of the Kerri-Kerri Basin Northeastern Nigeria. Jour. Min. Geol.29, 2, 77-93.
Dike, E. F. C. and Onumara. I. S., (1999). Facies and facies architecture, and depositional environments of the Gombe Sandstone, Gombe and Environs, NE Nigeria. Abstr. Vol. Sci. Assoc. Nig. Annual Confer. Bauchi.

Grant, N. K., (1971). The South Atlantic Benue Trough and Gulf of Guinea Cretaceous Tripple Geol. Sci. of American. Bull. 82: 2295-2298.

Guiraud. M., (1990). Tectono-sedimenatry framework of the Early Cretacecous continental Bima Formation (Upper Benue Trough N.E. Nigeria). Jour. Afr. Earth Sci., 10: 41-353.

Guiraud, M. and Plazait, J., (1993). Seismites in the fluviatile Bima Sandstone: identification of paleomagnetism and discussion of their magnitudein a Cretaceous synsedimentary strike-slip basin (Upper Benue, Nigeria). Tectonophysics, 225: 493-522.

Jones, A. P. and Omoto, K. (2000). Towards establishing criteria for identifying trigger mechanism for soft sediment deformation: A case study of the Pleistocene lacusrine sands and clays, Onokibe and Nakayamadaira Basin, northeastern Japan. Sedimentology, 47: 1211-1226.

Kleverlan, K., (1987). Gordo megabeds: possible seismites in a Tortonian submarine fans, Tabernas Basin, Province Almaria southeast Spain. Sedimentary Geology, 51: 165-180.

Lawal, O. and Maullde, M., (1986). Palynological biostratgraphy of the Cretaceous sediment of the Upper Benue Basin N.E. Nigeria. Revenue Micropaleontologic, 29: 61-83.

Lowe, D.R., (1975). Water seepage in the coarse grained sediments. Sedimentology, 22:157-204.

Maltman, A.J., (1994). The geological deformation of sediments. Chapman and Hall, London.

Obermeier, S.F., (1996). Uses of liquefaction-induced features for paleoseismic analysis. Engineering Geology, 44: $1-76$.

Olade, M. A., (1974). Evolution of Nigerian's Benue Trough (aulacogen): a tectonic model. Geological Magazine, 112: 575-583.

Owen, G., (1987). Deformed processes in unconsolidated sand In: M.E. Jones and R.M.E. Pieston (eds); Deformation of sediments and sedimentary rocks. Special Publication of Geological Society of London, 29: 1114.

Owen, G., (1995). Soft sediment deformation in Upper Proterozoic Torridonian Sandstones, northwestern Scotland. J. Sediment. Res. A.65, 495-504.

Owen. G. (1996). Experimental soft sediment deformation structure formed by the liquefaction of unconsolidated sands and some ancient examples. Sedimentology, 43, pp. 279-293.

Popoff. M., Wiedmann, J. and De Klazz, I., (1986). The Upper Cretaceous Gongila and Pindiga Formations, North-eastern Nigeria. Subdivisions, age stratigraphic correlations and paleogeographic implications. Ecologea Geol. Helv., 79,343-363.

Rebelle, M. (1990). The marine transgression in the Benue Trough (NE Nigeria): a palaeogeographic 
interpretation of the Gongila Formation. Jour. Afric. Earth Sciences, 10: 643-655.

Samaila, N. K., Abubakar, M. B., Dike, E.F.C. and Obaje, N. G., (2006). Description of soft sediment structure in the Cretaceous Bima Sandstone from the Yola Arm, Upper Benue Trough, northeastern Nigeria. Journal of African Earth Sciences, 44: 66-74.

Seilacher, A. (1984). Sedimentary structures tentatively attributes to seismites: Marine Geology, 5: 1-12.

Shettima, B., Dike, E.F.C., Abubakar, M. B. and Yusuf, A. V. (2007). Facies and facies architecture and depositional environments of the Cretaceous Yolde Formation in the Gongola Arm of the Upper Benue Trough, Nigeria. Nigeria. $43^{\text {rd }}$ Nigerian Mining and Geosciences Society (NMGS) Annual International Conference Akure. Abstract Vol, 9p.

Zaborski, P., Ugodunlunwa, F., Idornigie, A., Nnabo, P. and Ibe, K., (1997). Stratigraphy and structure of the Cretaceous Gongola Basin, Northeastern Nigeria. Elf Exploration Production, 21(1): 153-177. 